\title{
Activating Telomerase TERT Promoter Mutations and Their Application for the Detection of Bladder Cancer
}

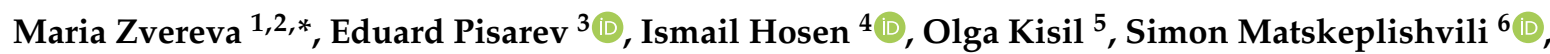 \\ Elena Kubareva ${ }^{7}$, David Kamalov ${ }^{6}$, Alexander Tivtikyan ${ }^{6}$, Arnaud Manel ${ }^{8}$, Emmanuel Vian ${ }^{9}$, \\ Armais Kamalov ${ }^{6}$, Thorsten Ecke ${ }^{10}{ }^{10}$ and Florence Le Calvez-Kelm ${ }^{2}$ \\ 1 Chair of Chemistry of Natural Compounds, Department of Chemistry, Lomonosov Moscow State University, \\ 119991 Moscow, Russia \\ 2 International Agency for Research on Cancer (IARC), 69372 Lyon, France; lecalvezf@iarc.fr \\ 3 Faculty of Bioengineering and Bioinformatics, Lomonosov Moscow State University, 119234 Moscow, Russia; \\ profard95@gmail.com \\ 4 Department of Biochemistry and Molecular Biology, Faculty of Biological Sciences, University of Dhaka, \\ Dhaka 1000, Bangladesh; ismail.hosen@du.ac.bd \\ 5 Gause Institute of New Antibiotics, 119021 Moscow, Russia; olvv@mail.ru \\ 6 Medical Research and Education Center, Lomonosov Moscow State University, 119992 Moscow, Russia; \\ simonmats@yahoo.com (S.M.); davidffm@mail.ru (D.K.); aleksandertivtikyan@yandex.ru (A.T.); \\ kamalov@mc.msu.ru (A.K.) \\ 7 Belozersky Institute of Physico-Chemical Biology, Moscow State University, 119992 Moscow, Russia; \\ kubareva@belozersky.msu.ru \\ 8 Le Creusot Hospital, 71200 Le Creusot, France; manelarnaud69@gmail.com \\ 9 Department of Urology, Protestant Clinic of Lyon, 69300 Lyon, France; emmanuel.vian@gmail.com \\ 10 Department of Urology, HELIOS Hospital Bad Saarow, D-15526 Bad Saarow, Germany; \\ thorsten.ecke@helios-gesundheit.de \\ * Correspondence: mzvereva@chem.msu.ru; Tel.: +7-49-5939-4533
}

Received: 31 July 2020; Accepted: 18 August 2020; Published: 21 August 2020

\begin{abstract}
This review summarizes state-of-the-art knowledge in early-generation and novel urine biomarkers targeting the telomerase pathway for the detection and follow-up of bladder cancer (BC). The limitations of the assays detecting telomerase reactivation are discussed and the potential of transcription-activating mutations in the promoter of the TERT gene detected in the urine as promising simple non-invasive BC biomarkers is highlighted. Studies have shown good sensitivity and specificity of the urinary TERT promoter mutations in case-control studies and, more recently, in a pilot prospective cohort study, where the marker was detected up to 10 years prior to clinical diagnosis. However, large prospective cohort studies and intervention studies are required to fully validate their robustness and assess their clinical utility. Furthermore, it may be interesting to evaluate whether the clinical performance of urinary TERT promoter mutations could increase when combined with other simple urinary biomarkers. Finally, different approaches for assessment of TERT promoter mutations in urine samples are presented together with technical challenges, thus highlighting the need of careful technological validation and standardization of laboratory methods prior to translation into clinical practice.
\end{abstract}

Keywords: bladder cancer; biomarkers; non-invasive detection; telomerase; somatic mutations; TERT promoter region

\section{Introduction}

More than 300 thousand new cases of bladder cancer (BC) are diagnosed in the world annually [1]. Currently, the gold standard of $\mathrm{BC}$ diagnosis and monitoring is cystoscopy, which is an invasive, 
painful, and relatively expensive procedure [2]. In the last few years, urine components have attracted the intense focus of investigators aiming to discover novel biomarkers for detection of $\mathrm{BC}$, as urine is in direct contact with potentially malignant urothelium, is easy to obtain, and its testing should potentially be much more cost-effective.

Molecular markers for such analyses can be of different nature (nucleic acids, proteins, small-molecular-weight compounds), but should be directly linked to the cell processes that are altered during neoplastic transformation (for example, avoidance of programmed cell death through disruption of the telomerase pathway). The characterization of molecular genetic alteration changes, associated with the malignant cell transformation, in differentiation or metastatic potential has provided insights into the interplay of these oncogenic processes and the activation of telomerase and its components [3]. This activation is directly related to the disruption of the cell division control system and, therefore, leads to uncontrolled cell growth. It has been widely demonstrated that telomerase activity is enhanced in $85-90 \%$ of tumor cell types [4]. There are multiple underlying mechanisms of telomerase activation [5], but genetic alterations in the promoter region of telomerase reverse transcriptase (TERT), leading to both increased gene expression and activity of the enzyme, are considered the most frequent. Therefore, they are considered highly promising putative biomarkers of cancer [6]. The process of reactivating the telomerase enzyme includes alterations in the gene promoter of the catalytic subunit of telomerase caused by methylation [7] and somatic mutations [8], both leading to its overexpression.

In this review, we trace the history of the early-generation of urine BC biomarkers identified in the telomerase pathway, discuss the limitations of the detection of related assays, and highlight the potential of transcription-activating mutations in the promoter of the TERT gene detected in the urine as promising simple non-invasive biomarkers for the detection of $\mathrm{BC}$ and surveillance for its relapse. Mutations in the TERT promoter have been shown to occur in many histological tumor types, making these alterations the most frequent somatic abnormalities detected in cancer so far. In BC particularly, they are detected in $60-85 \%$ of cases in all stages and grades of the disease. These mutations have been detected in the intracellular and extracellular DNA fragments from urine samples collected both at the time of primary clinical diagnosis of $\mathrm{BC}$ and during post-surgical follow-up. Therefore, they represent promising biomarkers to detect and monitor BC [9]. Recent publications reveal an important short-term clinical perspective of the use of TERT promoter mutations as $B C$ urinary biomarkers [10,11]. However, additional validations in large prospective cohort studies and interventional studies are necessary to fully assess their clinical performance and utility. Moreover, it is necessary to evaluate whether the sensitivity of the urinary TERT promoter mutations in detecting BC is increased when combined with other urinary biomarkers. Finally, careful technological validation and standardization of laboratory methods for assessing TERT promoter mutations in urine samples are critical for their clinical implementation.

\section{Telomerase Reactivation in Bladder Cancer and Early-Generation of Telomerase Urinary-Based Biomarkers}

Telomerase reactivation in BC has been first described in the mid-1990s [12]. Telomerase is an RNA-protein machinery that synthesizes repeating telomeric DNA. Telomeres are special structures at the ends of chromosomes where DNA interacts with specific proteins, shaping the "cap" to protect chromosome ends from degradation and to maintain their integrity [13]. Human telomerase contains a protein component (reverse transcriptase or hTERT) and a matrix RNA constituent (telomerase RNA, hTR), which, together with other proteins, form the active holoenzyme whose function is to extend telomeric DNA with new repeats and, therefore, revert the progressive loss of sequences at the ends of chromosomes associated with incomplete DNA replication [14]. In differentiated human cells, telomeres are typically shortened with every cell division up to a programmed critical length that leads to cell aging and apoptosis. During tumorigenesis, the mechanism leading to critical telomere shortening is counteracted by telomerase activation, thus preventing cell death. 
Enhanced through genetic or epigenetic changes, telomerase activity is, therefore, a telltale sign of malignancy [15]. Bladder cancer cells have shorter telomeres than adjacent normal urothelium [12]. Telomerase activity was shown to be high in $\mathrm{BC}$ tumor samples but not in the normal epithelium of patients with BC. Therefore, in many early studies, the measurement of telomerase activity as a biomarker of cancer diagnosis was considered. A relatively simple and accurate test called the Telomere Repeat Amplification Protocol (TRAP) was established to determine telomerase activity in cells and tissue samples [16]. The method relies on the amplification and measurement of the total number of telomeric repeats newly synthesized by the telomerase on a telomere-like oligonucleotide. Due to its direct contact to the urothelium, urine provides the most easily accessible reservoir of potential biomarkers to study urological diseases, so the possibility to use the TRAP assay to detect increased levels of telomerase secreted into the urine by bladder cancer cells has been tested. A case-control study involving 134 primary $\mathrm{BC}$ cases and 84 controls demonstrated promising performance of the urine TRAP assay with a sensitivity of $90 \%$ and specificity of $88 \%$ (when telomerase activity is 50 arbitrary enzymatic units (AEU)) in detecting the presence of bladder tumors in men [17]. While other studies reported a high sensitivity $(70-90 \%)$ compared to the current standard urine cytology, specificity proved to be lower, ranging from $66 \%$ to $88 \%$ [17-20]. The suboptimal of specificity has been attributed to the inherent telomerase activity in inflammatory or non-urothelial cells present in urine samples [21], which results in a significant variability in telomerase activity in urine of healthy individuals but also in cancer patients. This was observed by the same authors who reported an average value of telomerase activity of $27 \mathrm{AEU}$ (total range of 0-88) in urine of healthy individuals and $112 \mathrm{AEU}$ (total range of 30-382) in bladder cancer patients [17]. Another limitation of this method, which possibly reflects the lack of reproducibility between studies, includes the sensitivity of urine samples to inactivating agents that rapidly reduce the activity of the enzyme, giving rise to the need for strict protocols of handling samples at special conditions between sample collection and processing in order to maintain stability of the RNA-protein complex. Therefore, the lack of standardization of the TRAP assay and difficulties due to the technical requirements limit its use as a clinical biomarker for bladder cancer detection [22]. A recent alternative method to determine telomerase activity in human urine samples using the hybridization chain reaction and dynamic light scattering has been developed for the detection of bladder cancer [23]. Preliminary findings indicate a high specificity in cellular models and in few healthy individuals and patients with malignancies other than bladder cancer [24-26], but this needs to be confirmed in large case-control studies.

Another existing method to analyze telomerase reactivation is the quantitative measurement of the expression level of telomerase subunits TERT and telomerase RNA (TR) using real-time reverse transcription polymerase chain reaction (qRT-PCR). High expressions of these mRNAs have been observed consistently across many different malignancies, suggesting a promising avenue for early cancer detection in body fluids, especially in urine samples of patients with BC [27]. The quantitative analysis of TR and TERT in urine samples had an overall sensitivity of $77.0 \%$ and $55.2 \%$, respectively, and a specificity of $72.1 \%$ and $85.0 \%$, and determining both TERT mRNA and TR levels turned out to be more sensitive but less specific than urine cytology [28]. More recently, a protocol of combined modified TRAP and qRT-PCR methods to interrogate urine sediments gave encouraging results for the non-invasive detection of $\mathrm{BC}$ [29]. However, obstacles remain before urine telomerase activity-based assays can be translated into clinical practice [30]: (1) A high false-positive rate due to the telomerase activity of blood cells or non-urothelial cells in urine, which, despite attempts to sort out positive non-tumor cells, is yet to be solved; (2) an inconsistent correlation between TERT mRNA and telomerase activity in some tissues [31]; (3) a low number of telomerase-positive cells in urine in early stages of $\mathrm{BC}$, and (4) a possible high rate of telomerase or RNA degradation in the urine and serious technical constraints to maintain their stability. Based on the above considerations, it was of clinical interest to search for novel non-telomerase activity-based urinary biomarkers for the detection and surveillance of BC. Nowadays, several urine-based bladder cancer biomarkers have received FDA-approval: (1) The immunoassays based on the detection of the Nuclear matrix protein 22 
(NMP22 ${ }^{\circledR}$ BC and its improved variant, the NMP22 ${ }^{\circledR}$ BladderChek ${ }^{\circledR}$, Alere, Waltham, MA, USA) [32] and the detection of the complement factor H-related protein (BTA stat ${ }^{\circledR}$ and BTA TRAK ${ }^{\circledR}$ ); (2) the immunofluorescence assays based on the detection of the carcinoembryonic antigen and 2 mucins (ImmunoCyt $\mathrm{t}^{\mathrm{TM}} / \mathrm{uCyt}$ ), and (3) the multitarget fluorescence in situ hybridization (FISH) assay based on the detection of aneuploidy of several chromosomal regions (UroVysion) [33]. Other interesting commercially available biomarkers are emerging: The UBC ${ }^{\circledR}$ rapid (IDL, Bromma, Sweden) test to measure soluble fragments of cytokeratins 8 and 18 in urine [34] and the CxBladder test to identify the presence of five mRNAs (MDK, HOXA13, CDC2, IGFBP5, and CXCR2) in the urine [35]. Only few studies compared the performance of telomerase-based assays with FDA-approved tests for BC detection [32,36,37]. The UroVysion assay (FISH) had higher specificity than the TRAP assays and other urine markers; meanwhile, Bravaccini and colleagues showed that the combination of urine cytology and FISH to the TRAP assay had some potential in discriminating patients with bladder cancer from individuals with other urinary symptoms [36]. Another study conducted in a group of workers employed in the production of tires and, therefore, exposed to various potential bladder carcinogens, and in a control group of unexposed subjects showed that the two-step design using the TRAP assay with standard urine cytology and comet assay as the primary screening tool, and then FISH (UroVysion) in TRAP-positive cases increased the accuracy for the detection of BC as compared to the conventional urine cytology [38].

However, based on performance and cost considerations, none of the commercially available urine biomarkers to date are recommended as reliable diagnostic targets both by the European Association of Urology (link to NMIBC guideline https://uroweb.org/guideline/non-muscle-invasive-bladdercancer/\#5; link to MIBC guideline https://uroweb.org/guideline/bladder-cancer-muscle-invasive-andmetastatic/\#6) and American Urological Association (link to NMIBC guideline https:/www.auanet.org/ guidelines/bladder-cancer-non-muscle-invasive-guideline\#x2517) for routine BC clinical management or for screening in high-risk populations [39-42]. The absence of urine biomarkers that can be clinically exploited and the fact that the re-activation of telomerase is a crucial mechanism of urothelial carcinogenesis (observed in 99\% of urothelial carcinomas) rekindled the interest in further research on other markers indirectly influencing telomerase activation, for example, through recurrent genetic changes that have been identified in the regulatory elements of the TERT gene.

\section{Urinary TERT Promoter Mutations: The Holy Grail of a Biomarker for Bladder Cancer Detection and Surveillance?}

\subsection{TERT Promoter Mutations and Biological Significance in Bladder Carcinogenesis}

Since their discovery in 2013 in melanoma samples, mutations in the promoter region of the TERT gene have been found to be frequent in several tumor types [43]. Their functional impact has been well-characterized in vitro and associated with the creation of new binding sites to numerous cellular transcription factors, resulting in an increase in TERT expression and telomerase reactivation. [44,45]. The introduction of mutations in the TERT promoter sequence caused a two- to four-fold increase in promoter activity in reporter cell lines [44]. Thus, detection of such mutations can be seen as an indirect measure of telomerase reactivation and neoplastic transformation of cells.

Two hotspot mutations of the TERT promoter have been detected with high frequency in bladder cancer but not in neighboring normal tissues $[43,46,47]$. These mutations occur at two positions upstream of the transcription starting site, at -124 bp (nucleotide polymorphism G > A, g.1295228 (chr5, 1, 295, 228 assembly GRCh37) or g.1295113 (chr5, 1, 295, 113 assembly GRCh38)) and -146 bp (nucleotide polymorphism G > A, g.1295250 (chr5, 1, 295, 250, assembly GRCh37) or g.1295135 (chr5, 1, 295, 135 assembly GRCh38)) in a GC-rich genome region, which specifies its alternative organization (Figure 1). Reported to be mutually exclusive, somatic mutations in TERT promoter occur in $60-80 \%$ cases of all stages and grades of BC [40,48-53]. Specifically, Kinde et al. were the first to show that TERT promoter mutations occur frequently in low-grade, high-grade papillary tumors and carcinoma in situ lesions [54]. Allory et al. reported a TERT promoter mutation frequency of $87 \%$ in cell lines and 
of $83 \%$ in bladder tumors, regardless of stages or the risk associated with disease. Mutation frequency was virtually the same for low-risk non-muscle-invading bladder cancer (NMIBC) (73\%), high-risk NMIBC (74\%), and muscle-invading bladder cancer (MIBC) (53\%). These mutations occurred more frequently than any other genomic changes in both NMIBC risk categories. TERT promoter mutations were not shown to be associated with age, sex, or smoking [48]. In addition to urothelial carcinomas, these mutations have also been reported in other rare histological variants of primary BC, such as squamous cell carcinoma (SCC) [55], small cell carcinoma [56], adenocarcinoma of non-enteric type [57], and plasmacytoid urothelial carcinoma [58].

Furthermore, it has been shown that the two single nucleotide substitutions C228T and C250T together account for $99 \%$ of TERT promoter mutations in BC. Of the two-thirds of bladder tumors carrying a TERT promoter mutation, Rachakonda P.S. and colleagues observed that the C228T mutation ( $\mathrm{G}>\mathrm{A}$ ) was the most frequent change in BC followed by the C250T mutation, identified in $53.5 \%$ and $11.6 \%$ of all tumors, respectively [53]. Two additional rare nucleotide mutations were C228A (number of tumors, $n=3$ ) and 57A > C (T > G) -57 (nucleotide polymorphism A > C, g.1295161 (chr5, 1, 295, 161 assembly GRCh37) or g.1295046 (chr5, 1, 295, 046 assembly GRCh38), $(n=1)$ ). Mutations in all positions $-57,-124$, and -146 were mutually exclusive and resulted in the creation of a new common binding site de novo for transcription factors Ets/TCF. Similar results were obtained by Allory and colleagues [48]. The most frequent mutation was C228T $(n=65)$ followed by C250T $(n=10)$, and two additional rare mutations were C242T/C243T $(n=2)$ and C228A $(n=1)$. All mutations were mutually exclusive.

With regard to their potential as prognostic markers, one study investigated the relation between the disease-specific survival of patients with urothelial cancer and (1) the presence of C228T and C250T mutations in the TERT promoter; and (2) the level of TERT mRNA expression in two independent cohorts of previously untreated patients $(n=35$ and $n=87$ ). A significant decline in survival was strongly correlated with increased TERT mRNA level, but not with the presence of mutation in the TERT promoter [59]. Interestingly, the authors also demonstrated that the presence of a TERT mutation was associated with an increase in TERT mRNA expression level, leading to the enhancement in telomerase activity and telomere elongation. It has been hypothesized that this unexpected effect is due to the alternative functions of the telomerase catalytic subunit [60], and the existence of alternative mechanisms, other than mutations in the TERT promoter, such as epigenetic changes, also contribute to telomerase activation.

\subsection{Analytical Methods for Detecting Mutations in the TERT Promoter: Comparison of Analytical Performance and Bias}

There is a wide range of established analytical approaches for detecting mutations in the TERT promoter. However, the detection of these mutations is complicated by the composition and the structure of the TERT promoter genomic region, which is characterized by the highly GC-rich sequence and alternative structures of double stranded DNA in the form of G-quadruplexes, as illustrated in Figure 1 [61]. Another challenge is the detection of low-abundance tumor-derived mutations in body fluids. The DNA fragments carrying the tumor-specific alterations can represent a very small fraction of the total DNA. In blood samples, for example, the circulating tumor DNA fraction has been reported to be as low as $0.5 \%$ [62]. The analytical sensitivity of the assays is, therefore, critical in such settings. Despite such constraints, many quantitative PCR-based diagnostics described below have been successfully applied to human biological fluids, e.g., whole blood [63], urine (see Table 1), and urine samples of patients with hematuria (Table S4). 

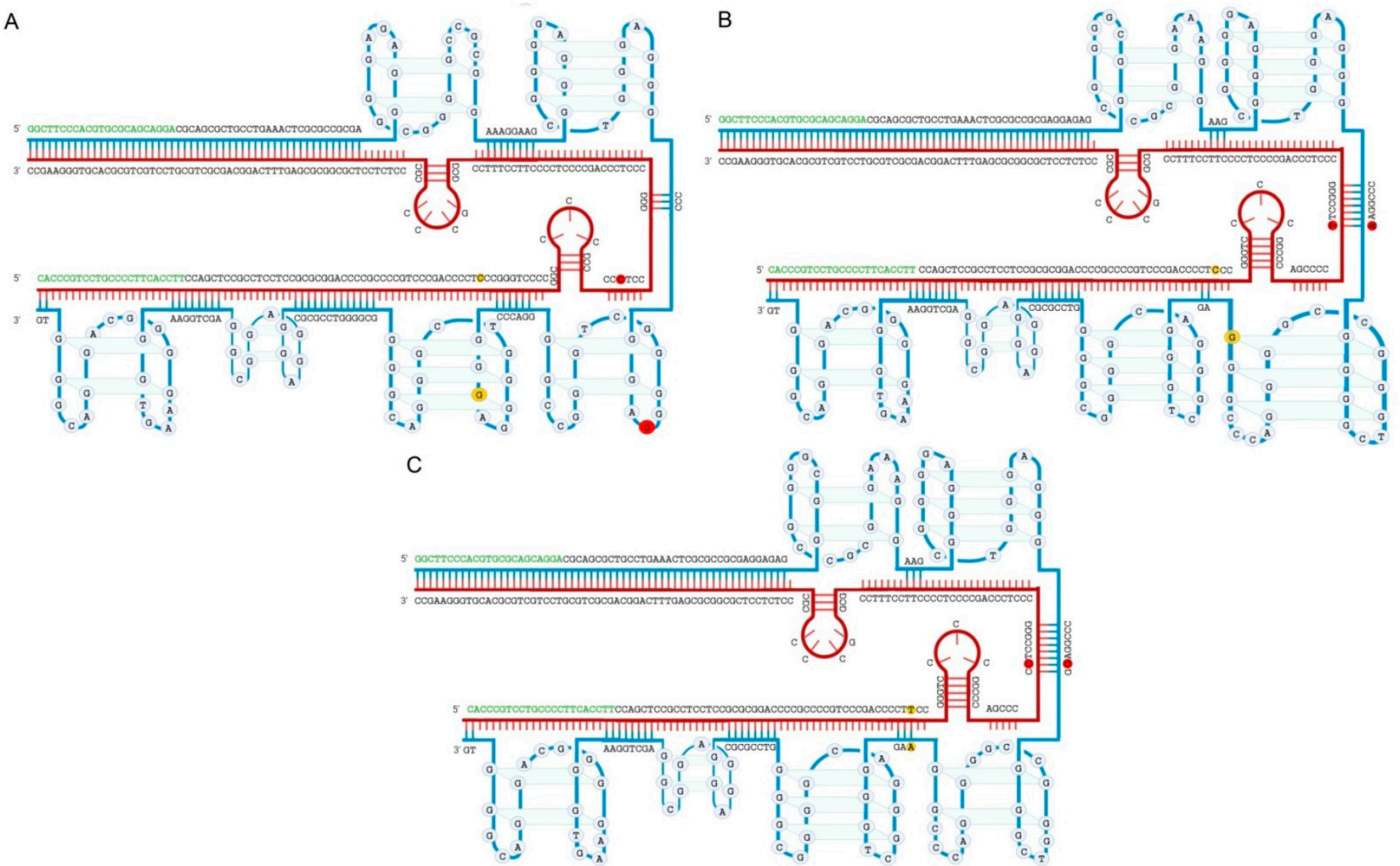

Figure 1. Predicted intramolecular distribution of putative Quadruplex forming G-Rich Sequences (QGRS) in the TERT promoter sequence. (A) the structure of wild type (WT) DNA; (B) only with mutation C228T; (C) only with mutation C250T. The two nucleotides at -124 and -146 positions from the ATG start site are highlighted with red and yellow circles respectively. These two hotspots affected by mutations predominantly including C228T and C250T are of the interest for both fundamental research and clinical diagnostics. G-strand and C-strand are marked in blue and claret lines respectively. Regions corresponding to the primers applied to amplify this fragment are marked in green. Despite the close resemblance between all three types of structures they differ substantially. The structures were obtained using online programs "QGRS Mapper" [64] (output data are provided in Tables S1-S3). In this manner both G- and C-strands were analyzed, however only G-strand contains G-quadruplexes. Procedure and software used to calculate and create the structures are described in the Supplementary Materials in more detail. 
Currently, the used method for detecting known genetic changes in clinical research is real-time PCR (quantitative PCR and its modifications). Yet, they often lack the sensitivity to detect underrepresented genetic alterations, so-called low mutant allelic fraction (MAF), which are often found diluted with wild-type DNA fragments originating from non-malignant cells or non-mutated cells. Furthermore, the heterogeneous composition of DNA fragments found in 'liquid biopsy' samples may also complicate the analysis. Studies that used real-time PCR to detect TERT promoter mutations in tumor and urine samples are shown in Table 1. Successful application of a qPCR-based method known as castPCR was described by Wang and co-workers [61]. In comparison to Sanger-sequencing, castPCR demonstrated dramatically higher sensitivity and specificity in a wide range of tumors of the urinary system (Table 1). The most recent progress with regard to the detection of TERT promoter mutations by qPCR has been achieved by Batista and colleagues who demonstrated that their sensitive, urine-based assay called Uromonitor ${ }^{\circledR}$ (Uromonitor Maia, Portugal) based on competitive allele-specific discrimination PCR was capable of detecting trace amounts of TERT promoter mutations in urine samples [65].

Next-generation sequencing (NGS) can simultaneously analyze millions of DNA copies. The identification of low-allelic somatic mutations requires ultra-deep sequencing so that the few sequencing reads with the mutant allele can be generated within the pool of wild-type reads. To achieve such high sequencing coverage of the screened genomic region(s), sequencing must be targeted. Traditional NGS-based targeted sequencing is able to detect mutant DNA forms at or higher than $2 \%$ allelic fraction against the background of the wild type DNA [66], but recent developments of NGS systems, such as Safe-SeqS [54,67], Tam-Seq [68,69], and CAPP-seq [70], improved threshold limits, the latter reaching an analytical sensitivity of $0.0025 \%$ MAF. Avogbe et al. recently developed UroMuTERT, a simple, non-invasive, and sensitive NGS-based assay for the detection of low-level TERT promoter mutations. Combined with a specific algorithm developed by the same group, called Needlestack [71], UroMuTERT achieved detection thresholds of $0.8 \%$ and $0.5 \%$ mutant allelic fraction MAFs for C228T and C250T mutations, respectively [10].

In addition to the next-generation sequencing methods, another platform that can detect low-abundance mutant DNA molecules against a background of the thousand-fold excess of wild-type molecules is droplet-digital PCR (ddPCR). It combines the short hands-on-time and easy laboratory workflows and does not require complex bioinformatic analysis (Table 1), making it highly suitable for implementation into clinical practice.

Figure 1 shows a possible organization of the TERT promoter region. This model was generated in the online server "QGRS Mapper" and the particular fragment shown on the picture was described [61] to determine mutations C228T and C250T in upper tract urothelial carcinomas (UTUC) using PCR in conjunction with subsequent Sanger sequencing. All the analytical approaches described above include an amplification step of genomic regions containing -124 and -146 sites from the ATG starting codon, whose length may vary according to primer design. The occurrence of C228T and C250T mutations can distort the double-stranded structure of this region, and the amplification efficiency may also be subject to the ability of primers to anneal and extend template DNA in such complex regions with secondary structures. This could explain the wide ranges of reported sensitivities and specificities.

To develop diagnostic approaches based on the identification of mutations in the promoter region of the TERT gene, it will be critical to compare the performance of screening methods and provide harmonized and standardized laboratory procedures. 
Table 1. Accuracy and methodological characteristics of tests for detecting the TERT promoter mutations in the urine for various neoplasias of the urinary system.

\begin{tabular}{|c|c|c|c|c|c|c|c|c|}
\hline Article & Tumor Type & Method & $\begin{array}{l}\text { Number of } \\
\text { Patients }\end{array}$ & $\begin{array}{l}\text { Size of } \\
\text { Control } \\
\text { Group }\end{array}$ & $\begin{array}{l}\text { Sensitivity } \\
\%\end{array}$ & $\begin{array}{l}\text { Specificity } \\
\%\end{array}$ & $\begin{array}{l}\text { Length of } \\
\text { PCR } \\
\text { Product }\end{array}$ & $\begin{array}{l}\text { Primers (Sequences Are Presented from } 5^{\prime} \text { End to End) } \\
\text { and Probes }\end{array}$ \\
\hline [56] & Small cell carcinoma (SCC) & $\begin{array}{l}\text { PCR+ Sanger } \\
\text { sequencing }\end{array}$ & 11 & 3 & 100 & 100 & 163 & $\begin{array}{l}\text { CAGCGCTGCCTGAAACTC; } \\
\text { GTCCTGCCCCTTCACCTT }\end{array}$ \\
\hline \multirow{8}{*}{ [61] } & \multirow{2}{*}{$\begin{array}{c}\text { Ureter carcinoma (UC) } \\
\text { Renal pelvic } \\
\text { carcinoma (RPC) }\end{array}$} & \multirow{2}{*}{$\begin{array}{l}\text { PCR+ Sanger } \\
\text { sequencing }\end{array}$} & 20 & 0 & 94 & 10 & 193 & \multirow{3}{*}{$\begin{array}{l}\text { CACCCGTCCTGCCCCTTCACCTT; } \\
\text { GGCTTCCCACGTGCGCAGCAGGA- }\end{array}$} \\
\hline & & & 16 & 0 & 93.8 & 25 & 193 & \\
\hline & \multirow[t]{2}{*}{$\mathrm{UTUC}(\mathrm{RPC}+\mathrm{UC}) \mathrm{C} 228 \mathrm{~T}$} & \multirow{2}{*}{$\begin{array}{l}\text { PCR+ Sanger } \\
\text { sequencing } \\
\text { castPCR }\end{array}$} & 10 & 37 & 60 & 97 & 193 & \\
\hline & & & 10 & 37 & 90 & 92 & dnp* & \multirow{5}{*}{$\begin{array}{r}\text { CACCCGTCCTGCCCCTTCACCTT; } \\
\text { GGCTTCCCACGTGCGCAGCAGGA } \\
\text { dnp } \\
\text { CACCCGTCCTGCCCCTTCACCTT; } \\
\text { GGCTTCCCACGTGCGCAGCAGGA } \\
\text { dnp }\end{array}$} \\
\hline & \multirow[b]{2}{*}{ BC (C228T) } & \multirow{4}{*}{$\begin{array}{l}\text { PCR+ Sanger } \\
\text { sequencing } \\
\text { castPCR } \\
\text { PCR+ Sanger } \\
\text { sequencing } \\
\text { castPCR }\end{array}$} & 36 & 33 & 47 & 100 & 193 & \\
\hline & & & 36 & 33 & 86 & 97 & dnp & \\
\hline & \multirow{2}{*}{$\mathrm{UTUC}+\mathrm{BC}$} & & 46 & 70 & 50 & 98 & 193 & \\
\hline & & & 46 & 70 & 89 & 96 & dnp & \\
\hline \multirow{3}{*}{ [10] } & \multirow{3}{*}{$\begin{array}{l}\text { Urothelial cancer (UC) } \\
\text { primary } \\
\text { Urothelial cancer (UC) } \\
\text { recurrence } \\
\text { UC (Diaguro) }\end{array}$} & \multirow{3}{*}{$\begin{array}{l}\text { UroMuTERT } \\
\text { (NGS) }\end{array}$} & 45 & 94 & 86.7 & 94.7 & 147 & \multirow{3}{*}{$\begin{array}{l}\text { CTTCCAGCTCCGCCTCCTCCGCGCGG; } \\
\text { AGCGCTGCCTGAAACTCGCGCC }\end{array}$} \\
\hline & & & 48 & 94 & 87.5 & 94.7 & 147 & \\
\hline & & & 93 & 94 & 87.1 & 94.7 & 147 & \\
\hline [72] & $\begin{array}{l}\text { Urothelial bladder } \\
\text { carcinoma }\end{array}$ & ddPCR & 99 & 376 & 81.8 & 83.5 & 60 & $\begin{array}{c}\text { C228T: CGGAAAGGAAGGGGAGGG;GTCCCCGGCCCAGC } \\
\text { Mut: [6FAM]-CCC+C+T+T+CCGG-[BHQ_1] } \\
\text { WT: [HEX]-CCCC+T+C+CGGG-[BHQ_1] } \\
\text { C250T: TGGGAGGGCCGGAG;GACCCGCCCCGT } \\
\text { Mut: [6FAM]CCC+C+T+T+CCGG[BHQ_1] } \\
\text { WT: [HEX]CCCC+T+C+CCGG[BHQ_1] }\end{array}$ \\
\hline [55] & $\begin{array}{l}\text { Squamous cell carcinoma } \\
\text { Benign transurethral } \\
\text { bladder biopsy } \\
\text { samples }\end{array}$ & Safe-SeqS & $\begin{array}{l}15 \\
0^{\mathrm{i}}\end{array}$ & $\begin{array}{c}94^{\mathrm{ii}} \\
8\end{array}$ & 80 & dnp & $\begin{array}{l}125 \\
\text { dnp }\end{array}$ & $\begin{array}{c}\text { 1st couple: CACACAGGAAACAGCTAT } \\
\text { GACCATGGGCCGCGGAAAGGAAG; } \\
\text { CGACGTAAAACGACGGCCAGTNNNNNNN } \\
\text { NNNNNNNCGTCCTGCCCCTTCACC ** } \\
\text { 2nd couple: } \\
\text { CACACAGGAAACAGCTATGAC } \\
\text { CATGGCGGAAAGGAAAGGGAG; } \\
\text { CGACGTAAAACGACGGCCAGTNNNNNN } \\
\text { NNNNNNNNCCGTCCCGACCCCTC }\end{array}$ \\
\hline [73] & NMIBC primary & SNaPshot assay & 230 & 0 & 69 & 52 & dnp & dnp \\
\hline
\end{tabular}


Table 1. Cont.

\begin{tabular}{|c|c|c|c|c|c|c|c|c|}
\hline Article & Tumor Type & Method & $\begin{array}{l}\text { Number of } \\
\text { Patients }\end{array}$ & $\begin{array}{l}\text { Size of } \\
\text { Control } \\
\text { Group }\end{array}$ & $\begin{array}{c}\text { Sensitivity } \\
\%\end{array}$ & $\begin{array}{c}\text { Specificity } \\
\%\end{array}$ & $\begin{array}{l}\text { Length of } \\
\text { PCR } \\
\text { Product }\end{array}$ & $\begin{array}{c}\text { Primers (Sequences Are Presented from } 5^{\prime} \text { End to End) } \\
\text { and Probes }\end{array}$ \\
\hline \multirow{3}{*}{ [48] } & $\mathrm{BC}$ (primary) & \multirow{3}{*}{ SNaPshot assay } & 118 & 0 & 62 & - & 155 & AGCGCTGCCTGAAACTCG; СССТTCACСТTCСAGCTC \\
\hline & $\mathrm{BC}$ (recurrence) & & 113 & 0 & 42 & - & 155 & Probes: for C228T/A $T_{23}$ GGCTGGGAGGGCCCGGA \\
\hline & $\mathrm{BC}$ (recurrence-free samples) & & 0 & 218 & - & 73 & 155 & for C250T T $\mathrm{T}_{39}$ CTGGGCCGGGGACCCGG \\
\hline \multirow{7}{*}{ [74] } & Renal pelvic carcinoma (RPC) & & 5 & 0 & 60 & dnp & 193 & \multirow{7}{*}{$\begin{array}{l}\text { CACCCGTCCTGCCCCTTCACCTT; } \\
\text { GGCTTCCCACGTGCGCAGCAGGA }\end{array}$} \\
\hline & UTUC & & 14 & 0 & 29 & dnp & 193 & \\
\hline & Chromophobe renal cell & & 8 & 0 & 13 & $\mathrm{dnp}$ & 193 & \\
\hline & carcinoma (CRCC) & & & & & & 190 & \\
\hline & Ureter carcinoma (UC) & & 9 & 0 & 11 & dnp & 193 & \\
\hline & $\begin{array}{l}\text { Clear cell renal cell } \\
\text { carcinoma (CCRCC) }\end{array}$ & & 96 & 0 & 9.3 & dnp & 193 & \\
\hline & Renal cell carcinoma ${ }^{\mathrm{iii}}$ (RCC) & & 109 & 0 & 9.2 & dnp & 193 & \\
\hline \multirow{2}{*}{ [75] } & BC early detection & \multirow[t]{2}{*}{$\begin{array}{l}\text { PCR + Illumina } \\
\text { sequencing }\end{array}$} & 570 & 188 & 57 & 99.4 & 126 & \multirow[t]{2}{*}{$\begin{array}{l}\text { GGCCGCGGAAAGGAAG; } \\
\text { CGTCCTGCCCCTTCACC }\end{array}$} \\
\hline & $\begin{array}{c}\text { UTUC } \\
\text { BC surveillance }\end{array}$ & & $\begin{array}{c}56 \\
322\end{array}$ & $\begin{array}{l}188 \\
188\end{array}$ & $\begin{array}{l}29 \\
57\end{array}$ & $\begin{array}{l}99.4 \\
99.4\end{array}$ & & \\
\hline [11] & $\mathrm{BC}$ & $\begin{array}{l}\text { UroMuTERT } \\
\text { and ddPCR }\end{array}$ & 30 & 101 & 46.7 & 100 & 65 & $\begin{array}{l}\text { C228T: CCCTCCCGGGTCC; CCGCGGAAAGGAAGG; } \\
\text { probes: Mut: CCCGGAaGGGGCTG (FAM_lowaBlack); } \\
\text { WT: CGGAgGGGGCTGG (HEX_IowaBlack). } \\
\text { C250T CTTCACCTTCCAGCTCC; GAGGGCCCGGAGG; } \\
\text { probes: Mut: CCCGGaAGGGGTCG (FAM_lowBlack); } \\
\text { WT: ACCCGGgAGGGGT (HEX_IowaBlack). }\end{array}$ \\
\hline$[47]$ & UTUC & ddPCR & 56 & 50 & 46.4 & 96 & 113 & dnp \\
\hline$[76]$ & $\begin{array}{c}\text { BC (supernatant) } \\
\text { BC (sediment) } \\
\text { Non-cancer hematuria }\end{array}$ & NGS & $\begin{array}{c}92 \\
92 \\
0\end{array}$ & $\begin{array}{c}0 \\
0 \\
33\end{array}$ & $\begin{array}{l}46 \\
48\end{array}$ & $\begin{array}{l}100 \\
100\end{array}$ & & $\begin{array}{l}\text { NGS-primers: ACCTTCCAGCTCCGCCTCCTCCGCGCGGAC; } \\
\text { AGAGGGCGGGGCCGCGGAAAGGAAGGGGAG }\end{array}$ \\
\hline [57] & $\begin{array}{l}\text { Benign transurethral bladder } \\
\text { biopsy samples }\end{array}$ & Safe-SeqS & 14 & $94^{\mathrm{iv}}$ & 28.6 & dnp & 125 & $\begin{array}{c}\text { 1st couple: CACACAGGAAACAGCTATGAC } \\
\text { CATGGGCCGCGGAAAGGAAG; } \\
\text { CGACGTAAAACGACGGCCAGTNNNNNNN } \\
\text { NNNNNNNCGTCCTGCCCCTTCACC } \\
\text { 2nd couple: } \\
\text { CACACAGGAAACAGCTATGAC } \\
\text { CATGGCGGAAAGGAAAGGGAG; } \\
\text { CGACGTAAAACGACGGCCAGTNNNNNN } \\
\text { NNNNNNNNCCGTCCCGACCCCTC }\end{array}$ \\
\hline [53] & Urothelial cell carcinoma & $\begin{array}{l}\text { PCR+ Sanger } \\
\text { sequencing }\end{array}$ & 327 & 0 & dnp & 65.4 & 343 & AGCACCTCGCGGTAGTGG; GGATTCGCGGGCACAGAC \\
\hline
\end{tabular}

* "dnp" -data not provided; ** "N" is a degenerate base (it can be A, T, G, or C with equal likelihood); ${ }^{\text {i }}$ Table fields with "Number of patients 0 " correspond to control group or additional control group; ii. Peripheral blood; iii. In this study, 6 subtypes of RCC tumor were investigated. In the table data only about 2 subtypes (ccRCC and chRCC) are presented. 4 remaining RCC tumors did not harbor TERT promoter mutations; iv. Peripheral blood. 


\subsection{Predictive Significance of Determining TERT Promoter Mutations in Urine}

The high frequency and the localization of mutations in a small region of the TERT promoter provided an extraordinary opportunity for a simple non-invasive assay for early detection or monitoring the recurrence or progression of disease in the patients whose tumors carry one of those variants. This is especially pertinent for the conception of an early detection test as TERT promoter mutations have been reported to be early events in the BC tumorigenesis process [54]. Normal urothelium cells and extracellular DNA (also called cell-free DNA or cfDNA) are constantly released into the urine. Malignant transformation of bladder tissue will lead to exfoliated tumor cells and circulating tumor DNA (also called ctDNA) to mix with normal cells and cfDNA in the urine.

TERT promoter mutations (C228T and C250T) have been previously detected in DNA from urinary exfoliated cells (cellDNA) collected prior to diagnosis and during post-surgical follow-up, with sensitivities and specificities varying from $52 \%$ to $82 \%$ and from $83 \%$ to $99 \%$, respectively, in patients with incident or early BC and from $42 \%$ to $74 \%$ and $73 \%$ to $93 \%$, respectively, in patients with recurrent BC $[48,54,72,73,75,77]$. Two studies reported a sensitivity of $80 \%$ using pre-surgery urine cellDNA but no information was provided on the primary or recurrence status $[46,50]$. The first indication these mutations detected in urine samples during follow-up was associated with recurrence and, therefore, could potentially serve as markers to monitor the disease status that was provided by the study conducted by Kinde et al. [54]. While limited in size, the authors showed that among patients whose tumors harbored TERT promoter mutations $(n=11)$, the same mutations were present in urine collected for follow-up in seven of eight patients with relapse but in none of the six patients without recurrence [54]. In line with these findings, Descotes and colleagues showed that, in particular, the presence of TERT mutant DNA forms in post-surgical urine samples was associated with recurrence in 100 patients initially diagnosed with NMIBC [46].

The association held true in a limited subset of patients with negative cystoscopy $(n=6)$, suggesting that TERT promoter mutations in urine could be a promising avenue for early detection of recurrence in patients under surveillance for BC. The same research group also showed that the detection of urinary mutations could be used as a dynamic monitoring of recurrence. This was illustrated in one patient for whom the absence of the initially detected C250T mutation was noted in post-diagnostic serial urine samples for 7 years before being detectable at the time of recurrence confirmed by cystoscopy. However, Allory et al. reported a relatively low specificity for the prediction of recurrence as mutations were detected in $27 \%$ of recurrence-free patients under surveillance for BC [48]. The high false-positive rate may reflect a timeline that is suboptimal for follow-up, which, if prolonged, may contribute to increase specificity, as patients with clinically undetectable tumors at the time of a TERT promoter mutation positive test may present with clinically detectable tumors later on. More well-powered longitudinal studies with sufficient follow-up durations and serial post-surgery urine samples are required to fully assess the true performance of these biomarkers for the prediction of $\mathrm{BC}$ recurrence.

There is growing evidence supporting the utility of urinary TERT promoter mutations to detect primary BC. Allory and colleagues first reported a sensitivity of $62 \%$ for the detection of primary BC with a specificity of $90 \%$ in individuals with hematuria but no bladder tumor [48] (Table 1 and Table S4). Combining urinary TERT promoter mutations with other DNA-based markers was also evaluated [72,75]. In a prospective blinded study, urine samples from 475 patients with gross hematuria collected at the time of standard urological examination (flexible cystoscopy and computed tomography urography) were tested for DNA mutation (TERT and FGFR3) and methylation biomarkers (SALL3, ONECUT2, CCNA1, BCL2, EOMES, and VIM) to determine whether a urine-based DNA test could replace flexible cystoscopy in the initial assessment of the most common BC symptom, i.e., gross hematuria. Of the $99(20.8 \%)$ patients presenting urothelial bladder tumors, the DNA test had a sensitivity of $97.0 \%$ and a specificity of $76.9 \%$. Detection of mutations in the TERT promoter showed the highest sensitivity $(81.8 \%)$, but at the same time, the lowest specificity $(83.5 \%)$ for individuals with hematuria [72] (Table 1 and Table S4). The FGFR3 gene is the most frequently mutated gene in NMIBC 
with a total frequency of $70 \%$. While they are much less frequent than TERT promoter mutations, they could still represent a putative interesting combined biomarker for the detection of BC. The added value of their combination with TERT promoter mutations for the comprehensive non-invasive detection of $\mathrm{BC}$ has to still be demonstrated in independent study. A combined DNA-based biomarker approach was also recently evaluated in a screening study conducted by Springer et al. where they assessed the performance of a multigene panel assay that includes the screening of TERT promoter mutations and regions of interest in ten other somatically mutated genes (UROSEEK) for detecting BC 0-18 months prior to clinical diagnosis in high-risk symptomatic patients. The authors reported a sensitivity of $83 \%$ and a specificity of $93 \%$ for their panel, while TERT promoter mutations were detected in $57 \%$ of the cases. Specifically, the sensitivity and specificity of the TERT promoter mutation in urine samples of individuals with hematuria were $55 \%$ and $90 \%$, respectively (Table S4) [75]. In a recent case-control study, Avogbe et al. used their developed single-plex ultrasensitive UroMuTERT assay to test the urinary DNA samples (both cfDNA or cellDNA) of 93 primary and recurrent cases with urothelial cancer and 94 controls, and compare its performance to that of urine cytology for the detection of urothelial cancer [10]. C228T or C250T mutations were detected in urinary cfDNA or cellDNA with $87.1 \%$ sensitivity and $94.7 \%$ specificity. The UroMuTERT sensitivity was consistent across primary and recurrent cases, and tumor stages and grades, and highest for urinary cfDNA and cellDNA combined. It also significantly outperformed the sensitivity of urine cytology, especially for detection of low-grade early-stage urothelial cancer [10]. In addition, the UroMuTERT single-gene assay demonstrated comparable performance to that of the UroSEEK multiple markers assay (including C228T and C250T) for the detection of primary or early urothelial cancer (sensitivity of $86.7 \%$ versus $83 \%$; specificity of $94.7 \%$ versus $93 \%$ ). Therefore, more studies are required to understand whether the observed differences in the detection rate of urinary TERT promoter mutations may originate from pre-analytical procedures or from the use of multiple urinary DNA sources versus one or from differences in prevalence of TERT promoter mutations in BC across populations. This has important implications as a simple single-gene assay with harmonized and standardized procedures for urine collection and processing might be able to achieve the same clinical performance for the detection of $\mathrm{BC}$ as complex multi-gene assays, which are more expensive and clinically less easily implemented.

While most studies conducted so far have focused on the evaluation of urinary cellDNA, there is, in addition to what Avogbe and colleagues reported [10], accumulating evidence that urinary cfDNA could be a reliable alternative source of urinary DNA for non-invasive genomic profiling of BC. While being based on recurrent clinically actionable genomic aberrations rather than on the assessment on TERT promoter mutations, a study reported that the use of urinary cfDNA led to higher analytical sensitivity $(90 \%)$, as well as the use of urinary cellDNA $(61 \%)$ for the detection of UC tumor-associated alterations [78]. These findings are in line with an initial study from 2007 reporting the superiority of urinary cfDNA over cellDNA for the detection of genetic alterations of patients with urothelial cancer [78,79]. Applied to the detection of the TERT promoter mutations, two recent studies highlighted the potential of the marker in urinary cfDNA for the detection of $B C[80,81]$. Specifically, of 77 patients whose tumor cells carried the $228 \mathrm{G}>\mathrm{A} / \mathrm{T}$ mutation, the same mutation was detected by ddPCR in urinary cfDNA of 71 individuals (92\%) and the mutation was absent in cfDNA of 26 of 27 healthy patients (specificity of $96 \%$ ). Patients with false-negative results had an early-stage tumor, and increased mutant allelic fraction was found to correlate with increased stages of the disease. Concordant mutational status between tumor tissues and liquid biopsy was obtained in $92 \%$ of cases [80]. However, in studies comparing the analytical sensitivity of both forms of urinary DNAs, the results are sparse. Stasik and colleagues demonstrated a better sensitivity in using cellDNA (83\%) than in using cfDNA (77\%), but, overall, the TERT mutation allelic frequencies (MAF) were highly correlated, suggesting little added value in using cfDNA as an alternative source of urinary DNA [2]. This observation is in agreement with the results from Ward et al. who demonstrated an equal ability to detect somatic tumor mutations in cfDNA and cellDNA [82]. Avogbe and co-workers also reported an overall high concordance between cfDNA and cellDNA results but still observed the highest sensitivity for the combined source 
of DNA $(87.1 \%)$ as opposed to cfDNA only $(81.8 \%)$ and cellDNA $(83.5 \%)$, highlighting the potential utility of combining multiple sources of DNA for the assessment of the marker in rare cases presenting with discordant results between cfDNA and cellDNA [10]. Interestingly, Stastik et al. observed a potential advantage of using urinary cfDNA in leukocyte-rich urines where the mutant allelic fractions of TERT promoter mutations were higher in cfDNA than in cellDNA [2].

In order to validate promising biomarkers, expert groups recommend a nested case-control study design within prospective cohorts in which samples collected at enrolment within the targeted population will be tested for the biomarker(s) in asymptomatic individuals who will develop cancer later and those who will not $[83,84]$. This sort of study was recently conducted by Hosen et al. who investigated the potential of urinary TERT promoter mutations as early detection biomarkers for bladder cancer in asymptomatic individuals in a case-control study nested within a longitudinal population-based prospective cohort of 50,045 Iranian individuals (the Golestan Cohort Study). TERT promoter mutations were assessed in baseline urine samples (1.9-4.5 mL) from 38 individuals who subsequently developed primary BC and 152 matched controls using the UroMuTERT and droplet digital PCR assays. Sequencing results were obtained for 30 cases and 101 controls. TERT promoter mutations were detected in 14 pre-clinical cases (sensitivity 46.67\%) and none of the controls (specificity $100.00 \%$ ). Most notably, the mutations were detectable up to 10 years prior to clinical diagnosis, indicating that detecting pre-clinical BC using cost-effective urinary TERT biomarkers may provide a valuable opportunity for BC screening and management [11].

Avogbe and colleagues [10] developed a predictive assay UroMuTERT, based on NGS (single-plex assay) of the hTERT promoter and the certain algorithm for detecting mutations of low-allelic fractions. Mutations in the TERT promoter in the urine DNA (cfDNA or cellDNA) showed superior sensitivity and specificity compared to all the methods described above, significantly surpassing the urine cytology especially for detecting early-stage NMIBC, which allowed the authors to propose modifications to the classic diagnostic protocol. The high recurrence rates of bladder cancer require frequent follow-ups involving expensive and invasive cystoscopic examination, thus further increasing the already high initial expenses for the management of bladder cancer $[85,86]$. The average costs of cystoscopy are around $\$ 206$, and the cost of non-invasive urine cytology is around $\$ 56$ [87]. By contrast, the cost of the NGS-based and ddPCR assays for detecting urinary TERT promoter mutations in bladder cancer developed by our group [10,11] is about $24 €$ per sample, and, therefore, has the potential to be easily implemented for cost-effective bladder cancer management strategies.

\section{Conclusions}

In summary, urinary TERT promoter mutations have demonstrated significant potential to be used as reliable, inexpensive, and non-invasive biomarkers for early detection and monitoring of $B C$. Moreover, urine ddPCR-based assays have been shown to be capable of detecting very low levels of these mutations, cost-effective, and simple to use, and would therefore represent an attractive method for clinical practice. The fact that TERT promoter mutations have been identified in urine years prior to the primary clinical diagnosis of $\mathrm{BC}$ and in some relapse-free patients under surveillance reflects the early occurrence of the mutations in the primary carcinogenic and in the relapse processes, providing a window of opportunity for early molecular detection and intervention. It may also explain the lack of specificity in some studies with the insufficient duration of follow-up. Therefore, large studies with a long-duration follow-up should further assess the robustness of these biomarkers for both detection and surveillance of BC. In particular, it should be evaluated whether a clinical diagnosis can be made through cystoscopy or urography in asymptomatic individuals or patients under surveillance presenting with a positive urinary TERT promoter mutations assay, or they would benefit from regular TERT mutation screening until the tumor becomes detectable.

Studies have shown that screening the high-risk population for bladder cancer with robust urinary markers, while not recommended by urological societies at present, could be cost-effective. Should their clinical relevance be demonstrated in individuals at high-risk of developing the disease 
(i.e., subjects with symptoms, mainly hematuria and/or lower urinary tract symptoms, or subjects with occupational exposure to certain chemicals), this may increase awareness of bladder cancer risk and facilitate the implementation of screening strategies in defined high-risk groups who would benefit from close surveillance with a non-invasive test. Furthermore, early detection of primary or recurrent $B C$ using urinary TERT promoter mutations as a primary tool should lead to timely therapeutic intervention and better survival. It should also reduce both the numbers of unnecessary cystoscopy procedures in patients with a TERT promoter mutation negative test and the cost of clinical management of suspected BCs. In addition, as it is unlikely that TERT promoter mutations in BC could be detected in urine in all $\mathrm{BC}$ cases, it would be important to evaluate whether the clinical performance of this promising and already successfully applied biomarker could further increase when combined with existing urinary biomarkers, which alone lacks the sensitivity and specificity for clinical utility.

Finally, the origin of the occurrence of the TERT promoter mutations and their correlation to the $\mathrm{BC}$ phenotype still have to be elucidated. Future research on the etiologies of mutations occurrence in certain parts of the genome leading to enhanced activity of the TERT promoter will result in a new practical understanding of the biology of $\mathrm{BC}$ and possibly the development of preventive approaches. With regard to potential therapeutic applications, it is worth noting that the region of the TERT promoter that frequently carries TERT promoter mutations in $\mathrm{BC}$, which are absent in normal bladder cells, can presumably become the target of anti-cancer therapy, including novel TERT-based immunotherapies, which could be tailored to patients whose tumors harbor these mutations $[88,89]$.

Supplementary Materials: The following are available online at http://www.mdpi.com/1422-0067/21/17/6034/s1, Table S1: G-quadruplexes of WT G-strand, Table S2: G-quadruplexes of G-strand with C228T, Table S3: G-quadruplexes of G-strand with C250T, Table S4: Applicability of different test systems to mutation analysis in patients with hematuria.

Funding: This research was supported by the Russian Foundation for Basic Research (grant no. 18-29-08040), the French Cancer League and the International Agency for Research on Cancer.

Conflicts of Interest: Where authors are identified as personnel of the International Agency for Research on Cancer/World Health Organization, the authors alone are responsible for the views expressed in this article and they do not necessarily represent the decisions, policy or views of the International Agency for Research on Cancer/World Health Organization.

\section{Abbreviations}

$\begin{array}{ll}\text { BC } & \text { Bladder cancer } \\ \text { NMIBC } & \text { Non-muscle-invasive bladder cancer } \\ \text { MIBC } & \text { Muscle-invasive bladder cancer } \\ \text { HTERT } & \text { Human telomerase reverse transcriptase } \\ \text { NGS } & \text { Next-generation sequencing } \\ \text { ddPCR } & \text { Droplet digital polymerase chain reaction }\end{array}$

\section{References}

1. Antoni, S.; Ferlay, J.; Soerjomataram, I.; Znaor, A.; Jemal, A.; Bray, F. Bladder Cancer Incidence and Mortality: A Global Overview and Recent Trends. Eur. Urol. 2017, 71, 96-108. [CrossRef] [PubMed]

2. Stasik, S.; Salomo, K.; Heberling, U.; Froehner, M.; Sommer, U.; Baretton, G.B.; Ehninger, G.; Wirth, M.P.; Thiede, C.; Fuessel, S. Evaluation of TERT promoter mutations in urinary cell-free DNA and sediment DNA for detection of bladder cancer. Clin. Biochem. 2019, 64, 60-63. [CrossRef] [PubMed]

3. Hannen, R.; Bartsch, J.W. Essential roles of telomerase reverse transcriptase hTERT in cancer stemness and metastasis. FEBS Lett. 2018, 592, 2023-2031. [CrossRef] [PubMed]

4. Jafri, M.A.; Ansari, S.A.; Alqahtani, M.H.; Shay, J.W. Roles of telomeres and telomerase in cancer, and advances in telomerase-targeted therapies. Genome Med. 2016, 8, 69. [CrossRef] [PubMed]

5. Yuan, X.; Larsson, C.; Xu, D. Mechanisms underlying the activation of TERT transcription and telomerase activity in human cancer: Old actors and new players. Oncogene 2019, 38, 6172-6183. [CrossRef] [PubMed] 
6. Leao, R.; Apolonio, J.D.; Lee, D.; Figueiredo, A.; Tabori, U.; Castelo-Branco, P. Mechanisms of human telomerase reverse transcriptase (hTERT) regulation: Clinical impacts in cancer. J. Biomed. Sci. 2018, $25,22$. [CrossRef] [PubMed]

7. Lee, D.D.; Leao, R.; Komosa, M.; Gallo, M.; Zhang, C.H.; Lipman, T.; Remke, M.; Heidari, A.; Nunes, N.M.; Apolonio, J.D.; et al. DNA hypermethylation within TERT promoter upregulates TERT expression in cancer. J. Clin. Investig. 2019, 129, 223-229. [CrossRef]

8. Chiba, K.; Lorbeer, F.K.; Shain, A.H.; McSwiggen, D.T.; Schruf, E.; Oh, A.; Ryu, J.; Darzacq, X.; Bastian, B.C.; Hockemeyer, D. Mutations in the promoter of the telomerase gene TERT contribute to tumorigenesis by a two-step mechanism. Science 2017, 357, 1416-1420. [CrossRef]

9. Gunes, C.; Wezel, F.; Southgate, J.; Bolenz, C. Implications of TERT promoter mutations and telomerase activity in urothelial carcinogenesis. Nat. Rev. Urol. 2018, 15, 386-393. [CrossRef]

10. Avogbe, P.H.; Manel, A.; Vian, E.; Durand, G.; Forey, N.; Voegele, C.; Zvereva, M.; Hosen, M.I.; Meziani, S.; De Tilly, B.; et al. Urinary TERT promoter mutations as non-invasive biomarkers for the comprehensive detection of urothelial cancer. EBioMedicine 2019, 44, 431-438. [CrossRef]

11. Hosen, M.I.; Sheikh, M.; Zvereva, M.; Scelo, G.; Forey, N.; Durand, G.; Voegele, C.; Poustchi, H.; Khoshnia, M.; Roshandel, G.; et al. Urinary TERT promoter mutations are detectable up to 10 years prior to clinical diagnosis of bladder cancer: Evidence from the Golestan Cohort Study. EBioMedicine 2020, 53, 17. [CrossRef] [PubMed]

12. Kamata, S.; Kageyama, Y.; Yonese, J.; Oshima, H. Significant telomere reduction in human superficial transitional cell carcinoma. Br. J. Urol. 1996, 78, 704-708. [CrossRef] [PubMed]

13. Turner, K.J.; Vasu, V.; Griffin, D.K. Telomere Biology and Human Phenotype. Cells 2019, 8, 73. [CrossRef]

14. Zvereva, M.I.; Shcherbakova, D.M.; Dontsova, O.A. Telomerase: Structure, functions, and activity regulation. Biochemistry 2010, 75, 1563-1583. [CrossRef]

15. Schmidt, J.C.; Cech, T.R. Human telomerase: Biogenesis, trafficking, recruitment, and activation. Genes Dev. 2015, 29, 1095-1105. [CrossRef] [PubMed]

16. Kim, N.W.; Piatyszek, M.A.; Prowse, K.R.; Harley, C.B.; West, M.D.; Ho, P.L.; Coviello, G.M.; Wright, W.E.; Weinrich, S.L.; Shay, J.W. Specific association of human telomerase activity with immortal cells and cancer. Science 1994, 266, 2011-2015. [CrossRef]

17. Sanchini, M.A.; Gunelli, R.; Nanni, O.; Bravaccini, S.; Fabbri, C.; Sermasi, A.; Bercovich, E.; Ravaioli, A.; Amadori, D.; Calistri, D. Relevance of urine telomerase in the diagnosis of bladder cancer. JAMA 2005, 294, 2052-2056. [CrossRef]

18. Landman, J.; Chang, Y.; Kavaler, E.; Droller, M.J.; Liu, B.C. Sensitivity and specificity of NMP-22, telomerase, and BTA in the detection of human bladder cancer. Urology 1998, 52, 398-402. [CrossRef]

19. Kinoshita, H.; Ogawa, O.; Kakehi, Y.; Mishina, M.; Mitsumori, K.; Itoh, N.; Yamada, H.; Terachi, T.; Yoshida, O. Detection of telomerase activity in exfoliated cells in urine from patients with bladder cancer. J. Natl. Cancer Inst. 1997, 89, 724-730. [CrossRef]

20. Yoshida, K.; Sugino, T.; Tahara, H.; Woodman, A.; Bolodeoku, J.; Nargund, V.; Fellows, G.; Goodison, S.; Tahara, E.; Tarin, D. Telomerase activity in bladder carcinoma and its implication for noninvasive diagnosis by detection of exfoliated cancer cells in urine. Cancer 1997, 79, 362-369. [CrossRef]

21. Sanchini, M.A.; Bravaccini, S.; Medri, L.; Gunelli, R.; Nanni, O.; Monti, F.; Baccarani, P.C.; Ravaioli, A.; Bercovich, E.; Amadori, D.; et al. Urine telomerase: An important marker in the diagnosis of bladder cancer. Neoplasia 2004, 6, 234-239. [CrossRef] [PubMed]

22. Sullivan, P.S.; Chan, J.B.; Levin, M.R.; Rao, J. Urine cytology and adjunct markers for detection and surveillance of bladder cancer. Am. J. Transl. Res. 2010, 2, 412-440. [PubMed]

23. Li, T.; Zou, L.; Zhang, J.; Li, G.; Ling, L. Non-invasive diagnosis of bladder cancer by detecting telomerase activity in human urine using hybridization chain reaction and dynamic light scattering. Anal. Chim. Acta 2019, 13, 90-97. [CrossRef] [PubMed]

24. Ludlow, A.T.; Robin, J.D.; Sayed, M.; Litterst, C.M.; Shelton, D.N.; Shay, J.W.; Wright, W.E. Quantitative telomerase enzyme activity determination using droplet digital PCR with single cell resolution. Nucleic Acids Res. 2014, 42, e104. [CrossRef] [PubMed]

25. Vukašinović, A.R.; Kotur-Stevuljević, J.M.; Mlakar, V.; Sopić, M.D.; Cvetković, Z.P.; Petković, M.R.; Spasojević-Kalimanovska, V.V.; Bogavac-Stanojević, N.B.; Ostanek, B. Telomerase stability and evaluation of real-time telomeric repeat amplification protocol. Scand. J. Clin. Lab. Investig. 2019, 79, 188-193. [CrossRef] 
26. Su, D.; Huang, X.; Dong, C.; Ren, J. Quantitative Determination of Telomerase Activity by Combining Fluorescence Correlation Spectroscopy with Telomerase Repeat Amplification Protocol. Anal. Chem. 2018, 90, 1006-1013. [CrossRef]

27. Müller, M. Telomerase: Its clinical relevance in the diagnosis of bladder cancer. Oncogene 2002, 21, 650-655. [CrossRef]

28. Weikert, S.; Krause, H.; Wolff, I.; Christoph, F.; Schrader, M.; Emrich, T.; Miller, K.; Müller, M. Quantitative evaluation of telomerase subunits in urine as biomarkers for noninvasive detection of bladder cancer. Int. J. Cancer 2005, 117, 274-280. [CrossRef]

29. Glukhov, A.I.; Grigorieva, Y.E.; Gordeev, S.A.; Vinarov, A.Z.; Potoldykova, N.V. Development of noninvasive bladder cancer diagnosis on basis of telomerase and it's subunits hTERT and hTR detection. Biomed. Khim. 2015, 61, 150-160. [CrossRef]

30. Tilki, D.; Burger, M.; Dalbagni, G.; Grossman, H.B.; Hakenberg, O.W.; Palou, J.; Reich, O.; Roupret, M.; Shariat, S.F.; Zlotta, A.R. Urine markers for detection and surveillance of non-muscle-invasive bladder cancer. Eur. Urol. 2011, 60, 484-492. [CrossRef]

31. Liu, K.; Hodes, R.J.; Weng, N. Cutting edge: Telomerase activation in human T lymphocytes does not require increase in telomerase reverse transcriptase (hTERT) protein but is associated with hTERT phosphorylation and nuclear translocation. J. Immunol. 2001, 166, 4826-4830. [CrossRef] [PubMed]

32. March-Villalba, J.A.; Panach-Navarrete, J.; Herrero-Cervera, M.J.; Aliño-Pellicer, S.; Martínez-Jabaloyas, J.M. hTERT mRNA expression in urine as a useful diagnostic tool in bladder cancer. Comparison with cytology and NMP22 BladderCheck Test ${ }^{\circledR}$. Actas Urológicas Españolas (Engl. Ed.) 2018, 42, 524-530. [CrossRef]

33. Clinton, T.; Lotan, Y. Review of the Clinical Approaches to the Use of Urine-based Tumor Markers in Bladder Cancer. Rambam Maimonides Med. J. 2017, 8, e0040. [CrossRef] [PubMed]

34. Ecke, T.H.; Weiß, S.; Stephan, C.; Hallmann, S.; Arndt, C.; Barski, D.; Otto, T.; Gerullis, H. UBC $\left({ }^{\circledR}\right)$ Rapid Test-A Urinary Point-of-Care (POC) Assay for Diagnosis of Bladder Cancer with a focus on Non-Muscle Invasive High-Grade Tumors: Results of a Multicenter-Study. Int. J. Mol. Sci. 2018, 19, 3841. [CrossRef] [PubMed]

35. O'Sullivan, P.; Sharples, K.; Dalphin, M.; Davidson, P.; Gilling, P.; Cambridge, L.; Harvey, J.; Toro, T.; Giles, N.; Luxmanan, C.; et al. A multigene urine test for the detection and stratification of bladder cancer in patients presenting with hematuria. J. Urol. 2012, 188, 741-747. [CrossRef] [PubMed]

36. Bravaccini, S.; Casadio, V.; Gunelli, R.; Bucchi, L.; Zoli, W.; Amadori, D.; Silvestrini, R.; Calistri, D. Combining cytology, TRAP assay, and FISH analysis for the detection of bladder cancer in symptomatic patients. Ann. Oncol. 2011, 22, 2294-2298. [CrossRef]

37. Halling, K.C.; King, W.; Sokolova, I.A.; Karnes, R.J.; Meyer, R.G.; Powell, E.L.; Sebo, T.J.; Cheville, J.C.; Clayton, A.C.; Krajnik, K.L.; et al. A comparison of BTA stat, hemoglobin dipstick, telomerase and Vysis UroVysion assays for the detection of urothelial carcinoma in urine. J. Urol. 2002, 167, 2001-2006. [CrossRef]

38. Cavallo, D.; Casadio, V.; Bravaccini, S.; Iavicoli, S.; Pira, E.; Romano, C.; Fresegna, A.M.; Maiello, R.; Ciervo, A.; Buresti, G.; et al. Assessment of DNA damage and telomerase activity in exfoliated urinary cells as sensitive and noninvasive biomarkers for early diagnosis of bladder cancer in ex-workers of a rubber tyres industry. Biomed. Res. Int. 2014, 2014, 370907. [CrossRef]

39. Schmitz-Dräger, B.J.; Droller, M.; Lokeshwar, V.B.; Lotan, Y.; Hudson, M.A.; van Rhijn, B.W.; Marberger, M.J.; Fradet, Y.; Hemstreet, G.P.; Malmstrom, P.U.; et al. Molecular markers for bladder cancer screening, early diagnosis, and surveillance: The WHO/ICUD consensus. Urol. Int. 2015, 94, 1-24. [CrossRef]

40. Larré, S.; Catto, J.W.; Cookson, M.S.; Messing, E.M.; Shariat, S.F.; Soloway, M.S.; Svatek, R.S.; Lotan, Y.; Zlotta, A.R.; Grossman, H.B. Screening for bladder cancer: Rationale, limitations, whom to target, and perspectives. Eur. Urol. 2013, 63, 1049-1058. [CrossRef]

41. Xylinas, E.; Kluth, L.A.; Rieken, M.; Karakiewicz, P.I.; Lotan, Y.; Shariat, S.F. Urine markers for detection and surveillance of bladder cancer. Urol. Oncol. 2014, 32, 222-229. [CrossRef] [PubMed]

42. Shegay, P.V.; Zhavoronkov, A.A.; Gaifullin, N.M.; Vorob'ev, N.V.; Alekseev, B.Y.; Popov, S.V.; Garazha, A.V.; Buzdin, A.A.; Kaprin, A.D. Potentialities of MicroRNA Diagnosis in Patients with Bladder Cancer. Bull. Exp. Biol. Med. 2017, 164, 106-108. [CrossRef] [PubMed]

43. Killela, P.J.; Reitman, Z.J.; Jiao, Y.; Bettegowda, C.; Agrawal, N.; Diaz, L.A., Jr.; Friedman, A.H.; Friedman, H.; Gallia, G.L.; Giovanella, B.C.; et al. TERT promoter mutations occur frequently in gliomas and a subset of tumors derived from cells with low rates of self-renewal. Proc. Natl. Acad. Sci. USA 2013, 110, 6021-6026. [CrossRef] [PubMed] 
44. Horn, S.; Figl, A.; Rachakonda, P.S.; Fischer, C.; Sucker, A.; Gast, A.; Kadel, S.; Moll, I.; Nagore, E.; Hemminki, K.; et al. TERT promoter mutations in familial and sporadic melanoma. Science 2013, 339, 959-961. [CrossRef]

45. Huang, F.W.; Hodis, E.; Xu, M.J.; Kryukov, G.V.; Chin, L.; Garraway, L.A. Highly recurrent TERT promoter mutations in human melanoma. Science 2013, 339, 957-959. [CrossRef]

46. Descotes, F.; Kara, N.; Decaussin-Petrucci, M.; Piaton, E.; Geiguer, F.; Rodriguez-Lafrasse, C.; Terrier, J.E.; Lopez, J.; Ruffion, A. Non-invasive prediction of recurrence in bladder cancer by detecting somatic TERT promoter mutations in urine. Br. J. Cancer 2017, 117, 583-587. [CrossRef]

47. Hayashi, Y.; Fujita, K.; Matsuzaki, K.; Matsushita, M.; Kawamura, N.; Koh, Y.; Nakano, K.; Wang, C.; Ishizuya, Y.; Yamamoto, Y.; et al. Diagnostic potential of TERT promoter and FGFR3 mutations in urinary cell-free DNA in upper tract urothelial carcinoma. Cancer Sci. 2019, 110, 1771-1779. [CrossRef]

48. Allory, Y.; Beukers, W.; Sagrera, A.; Flandez, M.; Marques, M.; Marquez, M.; van der Keur, K.A.; Dyrskjot, L.; Lurkin, I.; Vermeij, M.; et al. Telomerase reverse transcriptase promoter mutations in bladder cancer: High frequency across stages, detection in urine, and lack of association with outcome. Eur. Urol. 2014, 65, 360-366. [CrossRef]

49. Eich, M.-L.; Rodriguez Pena, M.D.C.; Springer, S.U.; Taheri, D.; Tregnago, A.C.; Salles, D.C.; Bezerra, S.M.; Cunha, I.W.; Fujita, K.; Ertoy, D.; et al. Incidence and distribution of UroSEEK gene panel in a multi-institutional cohort of bladder urothelial carcinoma. Mod. Pathol. 2019, 32, 1544-1550. [CrossRef]

50. Hurst, C.; Platt, F.; Knowles, M. Abstract 2240: TERT promoter mutations are highly prevalent in bladder cancer and represent a potential new urinary biomarker. Cancer Res. 2014, 74, 2240.

51. Kurtis, B.; Zhuge, J.; Ojaimi, C.; Ye, F.; Cai, D.; Zhang, D.; Fallon, J.T.; Zhong, M. Recurrent TERT promoter mutations in urothelial carcinoma and potential clinical applications. Ann. Diagn. Pathol. 2016, 21, 7-11. [CrossRef] [PubMed]

52. Pietzak, E.J.; Bagrodia, A.; Cha, E.K.; Drill, E.N.; Iyer, G.; Isharwal, S.; Ostrovnaya, I.; Baez, P.; Li, Q.; Berger, M.F.; et al. Next-generation Sequencing of Nonmuscle Invasive Bladder Cancer Reveals Potential Biomarkers and Rational Therapeutic Targets. Eur. Urol. 2017, 72, 952-959. [CrossRef] [PubMed]

53. Rachakonda, P.S.; Hosen, I.; de Verdier, P.J.; Fallah, M.; Heidenreich, B.; Ryk, C.; Wiklund, N.P.; Steineck, G.; Schadendorf, D.; Hemminki, K.; et al. TERT promoter mutations in bladder cancer affect patient survival and disease recurrence through modification by a common polymorphism. Proc. Natl. Acad. Sci. USA 2013, 110, 17426-17431. [CrossRef] [PubMed]

54. Kinde, I.; Munari, E.; Faraj, S.F.; Hruban, R.H.; Schoenberg, M.; Bivalacqua, T.; Allaf, M.; Springer, S.; Wang, Y.; Diaz, L.A., Jr.; et al. TERT promoter mutations occur early in urothelial neoplasia and are biomarkers of early disease and disease recurrence in urine. Cancer Res. 2013, 73, 7162-7167. [CrossRef]

55. Cowan, M.; Springer, S.; Nguyen, D.; Taheri, D.; Guner, G.; Rodriguez, M.A.; Wang, Y.; Kinde, I.; VandenBussche, C.J.; Olson, M.T.; et al. High prevalence of TERT promoter mutations in primary squamous cell carcinoma of the urinary bladder. Mod. Pathol. 2016, 29, 511-515. [CrossRef]

56. Zheng, X.; Zhuge, J.; Bezerra, S.M.; Faraj, S.F.; Munari, E.; Fallon, J.T., 3rd; Yang, X.J.; Argani, P.; Netto, G.J.; Zhong, M. High frequency of TERT promoter mutation in small cell carcinoma of bladder, but not in small cell carcinoma of other origins. J. Hematol. Oncol. 2014, 7, 014-0047. [CrossRef]

57. Cowan, M.L.; Springer, S.; Nguyen, D.; Taheri, D.; Guner, G.; Mendoza Rodriguez, M.A.; Wang, Y.; Kinde, I.; Del Carmen Rodriguez Pena, M.; VandenBussche, C.J.; et al. Detection of TERT promoter mutations in primary adenocarcinoma of the urinary bladder. Hum. Pathol. 2016, 53, 8-13. [CrossRef]

58. Palsgrove, D.N.; Taheri, D.; Springer, S.U.; Cowan, M.; Guner, G.; Mendoza Rodriguez, M.A.; Rodriguez Pena, M.D.C.; Wang, Y.; Kinde, I.; Ricardo, B.F.P.; et al. Targeted sequencing of plasmacytoid urothelial carcinoma reveals frequent TERT promoter mutations. Hum. Pathol. 2019, 85, 1-9. [CrossRef]

59. Borah, S.; Xi, L.; Zaug, A.J.; Powell, N.M.; Dancik, G.M.; Cohen, S.B.; Costello, J.C.; Theodorescu, D.; Cech, T.R. Cancer. TERT promoter mutations and telomerase reactivation in urothelial cancer. Science 2015, 347, 1006-1010. [CrossRef]

60. Ségal-Bendirdjian, E.; Geli, V. Non-canonical Roles of Telomerase: Unraveling the Imbroglio. Front. Cell Dev. Biol. 2019, 7, 332. [CrossRef]

61. Wang, K.; Liu, T.; Ge, N.; Liu, L.; Yuan, X.; Liu, J.; Kong, F.; Wang, C.; Ren, H.; Yan, K.; et al. TERT promoter mutations are associated with distant metastases in upper tract urothelial carcinomas and serve as urinary biomarkers detected by a sensitive castPCR. Oncotarget 2014, 5, 12428-12439. [CrossRef] [PubMed] 
62. Bettegowda, C.; Sausen, M.; Leary, R.J.; Kinde, I.; Wang, Y.; Agrawal, N.; Bartlett, B.R.; Wang, H.; Luber, B.; Alani, R.M.; et al. Detection of Circulating Tumor DNA in Early- and Late-Stage Human Malignancies. Sci. Transl. Med. 2014, 6, 224ra24. [CrossRef] [PubMed]

63. Srisuwan, W.; Tatu, T. A Simple Whole-Blood Polymerase Chain Reaction without DNA Extraction for Thalassemia Diagnosis. Hemoglobin 2018, 42, 178-183. [CrossRef]

64. Kikin, O.; D'Antonio, L.; Bagga, P.S. QGRS Mapper: A web-based server for predicting G-quadruplexes in nucleotide sequences. Nucl. Acids Res. 2006, 34, W676-W682. [CrossRef]

65. Batista, R.; Vinagre, J.; Prazeres, H.; Sampaio, C.; Peralta, P.; Conceição, P.; Sismeiro, A.; Leão, R.; Gomes, A.; Furriel, F.; et al. Validation of a Novel, Sensitive, and Specific Urine-Based Test for Recurrence Surveillance of Patients With Non-Muscle-Invasive Bladder Cancer in a Comprehensive Multicenter Study. Front. Genet. 2019, 10, 1237. [CrossRef] [PubMed]

66. Siravegna, G.; Marsoni, S.; Siena, S.; Bardelli, A. Integrating liquid biopsies into the management of cancer. Nat. Rev. Clin. Oncol. 2017, 14, 531-548. [CrossRef] [PubMed]

67. Kinde, I.; Wu, J.; Papadopoulos, N.; Kinzler, K.W.; Vogelstein, B. Detection and quantification of rare mutations with massively parallel sequencing. Proc. Natl. Acad. Sci. USA 2011, 108, 9530-9535. [CrossRef]

68. Forshew, T.; Murtaza, M.; Parkinson, C.; Gale, D.; Tsui, D.W.Y.; Kaper, F.; Dawson, S.-J.; Piskorz, A.M.; Jimenez-Linan, M.; Bentley, D.; et al. Noninvasive Identification and Monitoring of Cancer Mutations by Targeted Deep Sequencing of Plasma DNA. Sci. Transl. Med. 2012, 4, 136ra68. [CrossRef]

69. Gale, D.; Lawson, A.R.J.; Howarth, K.; Madi, M.; Durham, B.; Smalley, S.; Calaway, J.; Blais, S.; Jones, G.; Clark, J.; et al. Development of a highly sensitive liquid biopsy platform to detect clinically-relevant cancer mutations at low allele fractions in cell-free DNA. PLoS ONE 2018, 13, e0194630. [CrossRef]

70. Newman, A.M.; Bratman, S.V.; To, J.; Wynne, J.F.; Eclov, N.C.; Modlin, L.A.; Liu, C.L.; Neal, J.W.; Wakelee, H.A.; Merritt, R.E.; et al. An ultrasensitive method for quantitating circulating tumor DNA with broad patient coverage. Nat. Med. 2014, 20, 548-554. [CrossRef]

71. Delhomme, T.M.; Avogbe, P.H.; Gabriel, A.A.G.; Alcala, N.; Leblay, N.; Voegele, C.; Vallée, M.; Chopard, P.; Chabrier, A.; Abedi-Ardekani, B.; et al. Needlestack: An ultra-sensitive variant caller for multi-sample next generation sequencing data. NAR Genom. Bioinform. 2020, 2, 20. [CrossRef] [PubMed]

72. Dahmcke, C.M.; Steven, K.E.; Larsen, L.K.; Poulsen, A.L.; Abdul-Al, A.; Dahl, C.; Guldberg, P. A Prospective Blinded Evaluation of Urine-DNA Testing for Detection of Urothelial Bladder Carcinoma in Patients with Gross Hematuria. Eur. Urol. 2016, 70, 916-919. [CrossRef] [PubMed]

73. Critelli, R.; Fasanelli, F.; Oderda, M.; Polidoro, S.; Assumma, M.B.; Viberti, C.; Preto, M.; Gontero, P.; Cucchiarale, G.; Lurkin, I.; et al. Detection of multiple mutations in urinary exfoliated cells from male bladder cancer patients at diagnosis and during follow-up. Oncotarget 2016, 7, 67435-67448. [CrossRef] [PubMed]

74. Wang, K.; Liu, T.; Liu, L.; Liu, J.; Liu, C.; Wang, C.; Ge, N.; Ren, H.; Yan, K.; Hu, S.; et al. TERT promoter mutations in renal cell carcinomas and upper tract urothelial carcinomas. Oncotarget 2014, 5, 1829-1836. [CrossRef]

75. Springer, S.U.; Chen, C.-H.; Rodriguez Pena, M.D.C.; Li, L.; Douville, C.; Wang, Y.; Cohen, J.D.; Taheri, D.; Silliman, N.; Schaefer, J.; et al. Non-invasive detection of urothelial cancer through the analysis of driver gene mutations and aneuploidy. eLife 2018, 7, e32143. [CrossRef]

76. Ou, Z.; Li, K.; Yang, T.; Dai, Y.; Chandra, M.; Ning, J.; Wang, Y.; Xu, R.; Gao, T.; Xie, Y.; et al. Detection of bladder cancer using urinary cell-free DNA and cellular DNA. Clin. Transl. Med. 2020, 9, 4. [CrossRef]

77. Ward, D.G.; Baxter, L.; Gordon, N.S.; Ott, S.; Savage, R.S.; Beggs, A.D.; James, J.D.; Lickiss, J.; Green, S.; Wallis, Y.; et al. Multiplex PCR and Next Generation Sequencing for the Non-Invasive Detection of Bladder Cancer. PLoS ONE 2016, 11, e0149756. [CrossRef]

78. Togneri, F.S.; Ward, D.G.; Foster, J.M.; Devall, A.J.; Wojtowicz, P.; Alyas, S.; Vasques, F.R.; Oumie, A.; James, N.D.; Cheng, K.K.; et al. Genomic complexity of urothelial bladder cancer revealed in urinary cfDNA. Eur. J. Hum. Genet. 2016, 24, 1167-1174. [CrossRef]

79. Szarvas, T.; Kovalszky, I.; Bedi, K.; Szendroi, A.; Majoros, A.; Riesz, P.; Fule, T.; Laszlo, V.; Kiss, A.; Romics, I. Deletion analysis of tumor and urinary DNA to detect bladder cancer: Urine supernatant versus urine sediment. Oncol Rep. 2007, 18, 405-409. [CrossRef]

80. Russo, I.J.; Ju, Y.; Gordon, N.S.; Zeegers, M.P.; Cheng, K.K.; James, N.D.; Bryan, R.T.; Ward, D.G. Toward Personalised Liquid Biopsies for Urothelial Carcinoma: Characterisation of ddPCR and Urinary cfDNA for the Detection of the TERT 228 G > A/T Mutation. Bladder Cancer 2018, 4, 41-48. [CrossRef] 
81. Hayashi, Y.; Fujita, K.; Matsuzaki, K.; Eich, M.L.; Tomiyama, E.; Matsushita, M.; Koh, Y.; Nakano, K.; Wang, C.; Ishizuya, Y.; et al. Clinical Significance of Hotspot Mutation Analysis of Urinary Cell-Free DNA in Urothelial Bladder Cancer. Front. Oncol. 2020, 10, 755. [CrossRef] [PubMed]

82. Ward, D.G.; Gordon, N.S.; Boucher, R.H.; Pirrie, S.J.; Baxter, L.; Ott, S.; Silcock, L.; Whalley, C.M.; Stockton, J.D.; Beggs, A.D.; et al. Targeted deep sequencing of urothelial bladder cancers and associated urinary DNA: A 23-gene panel with utility for non-invasive diagnosis and risk stratification. BJU Int. 2019, 124, 532-544. [CrossRef] [PubMed]

83. Pepe, M.S.; Etzioni, R.; Feng, Z.; Potter, J.D.; Thompson, M.L.; Thornquist, M.; Winget, M.; Yasui, Y. Phases of biomarker development for early detection of cancer. J. Natl. Cancer Inst. 2001, 93, 1054-1061. [CrossRef] [PubMed]

84. Pesch, B.; Brüning, T.; Johnen, G.; Casjens, S.; Bonberg, N.; Taeger, D.; Müller, A.; Weber, D.G.; Behrens, T. Biomarker research with prospective study designs for the early detection of cancer. Biochim. Biophys. Acta 2014, 5, 874-883. [CrossRef] [PubMed]

85. Svatek, R.S.; Hollenbeck, B.K.; Holmäng, S.; Lee, R.; Kim, S.P.; Stenzl, A.; Lotan, Y. The economics of bladder cancer: Costs and considerations of caring for this disease. Eur. Urol. 2014, 66, 253-262. [CrossRef] [PubMed]

86. Leal, J.; Luengo-Fernandez, R.; Sullivan, R.; Witjes, J.A. Economic Burden of Bladder Cancer Across the European Union. Eur. Urol. 2016, 69, 438-447. [CrossRef] [PubMed]

87. Lotan, Y.; Svatek, R.S.; Sagalowsky, A.I. Should we screen for bladder cancer in a high-risk population?: A cost per life-year saved analysis. Cancer 2006, 107, 982-990. [CrossRef]

88. Zanetti, M. A second chance for telomerase reverse transcriptase in anticancer immunotherapy. Nat. Rev. Clin. Oncol. 2017, 14, 115-128. [CrossRef]

89. Carrozza, F.; Santoni, M.; Piva, F.; Cheng, L.; Lopez-Beltran, A.; Scarpelli, M.; Montironi, R.; Battelli, N.; Tamberi, S. Emerging immunotherapeutic strategies targeting telomerases in genitourinary tumors. Crit. Rev. Oncol. Hematol. 2018, 131, 1-6. [CrossRef]

(C) 2020 by the authors. Licensee MDPI, Basel, Switzerland. This article is an open access article distributed under the terms and conditions of the Creative Commons Attribution (CC BY) license (http://creativecommons.org/licenses/by/4.0/). 